\title{
Response Surface Optimization of Biodiesel Production from Nyamplung (Calophyllum inophyllum) Oil Enhanced by Microwave and Ionic liquid + $\mathrm{NaOH}$ Catalyst
}

\author{
Prima A. Handayani ${ }^{1,2^{*}}$, Abdullah Abdullah², Hadiyanto Hadiyanto ${ }^{2}$ \\ ${ }^{1}$ Department of Chemical Engineering, Faculty of Engineering, Universitas Negeri Semarang, Gedung E1 Lantai 2 Fakultas Teknik, \\ Kampus UNNES Sekaran Gunungpati, Semarang 50229, Indonesia \\ 2 Department of Chemical Engineering, Faculty of Engineering, Diponegoro University, Jl. Prof. Soedarto S.H., Tembalang, \\ Semarang 50239, Indonesia \\ * Corresponding author, e-mail: prima@mail.unnes.ac.id
}

Received: 08 August 2018, Accepted: 05 November 2018, Published online: 30 January 2019

\begin{abstract}
Nyamplung (Calophyllum inophyllum) plant is a highly potential raw material in the biodiesel production, the oil in the seeds is $50-73 \%$. The microwave has been intensively applied to reduce the processing time while ionic liquid also was used as an acceleration agent in the biodiesel production. The optimum process condition of the biodiesel production using lonic liquid $+\mathrm{NaOH}$ as a catalyst mixture and assisted with microwave heating system were determined in this study. Response Surface Methodology (RSM) was used to optimize three transesterification reaction variables: the catalyst concentration of $(0.5-1.5 \% \mathrm{wt})$, the reaction temperature of $60-80{ }^{\circ} \mathrm{C}$, and methanol to oil molar ratio of 6:1-12:1, while the transesterification time was set constant at 6 minutes. The optimization showed that the maximum biodiesel yield can be obtained was $95.8 \%$ at the catalyst concentration of $1.2 \%$ wt, the reaction temperature of $71.3^{\circ} \mathrm{C}$, and methanol to oil molar ratio of $10.8 \mathrm{~mole} / \mathrm{mole}$.
\end{abstract}

Keywords

biodiesel, transesterification, ionic liquid, microwave

\section{Introduction}

Biodiesel production has attracted numerous attentions due to its potential to substitute and to minimize the severe issues of fossil fuel. Biodiesel is a biofuel which can be produced from esterification of vegetable oil or animal fats. Nyamplung (Calophyllum inophyllum) is a plant which commonly found in Indonesia and its seed contains $75 \%$ oil, including an unsaturated fatty acid of $71 \%$ [1]. Crude Nyamplung oil also contains gums and free fatty acids up to $12.9 \%$. The pretreatment processes of crude oil such as degumming and neutralization are normally needed before processed to biodiesel. Oils or fats are reacted with alcohol (transesterification reaction) to produce fatty acid alkyl esters (biodiesel). The parameters affecting the transesterification reaction are temperature, catalyst concentration and molar ratio of methanol to oil [2]. The production of biodiesel from oil uses acid, base or biological catalysts to enhance the reaction. The base catalyst can take place at a low temperature and the reaction time relatively faster than acid and biological catalyst. However the base catalyst has a drawback such as it can cause the saponification due to high content of free fatty acid in the oil [3]. In addition, the use of homogeneous catalyst still produces low biodiesel yield and require a longer processing time. Therefore, another approach is required to reduce the time and increase the yield. One method is by using ionic liquids as catalyst and external power to accelerate the reaction.

The study of the biodiesel production using ionic liquids as a catalyst and microwave as a heating system were recently studied. The use of ionic liquids has been a widely studied in the recent years because it has the potential as a catalyst in the biodiesel production [4]. The ionic liquid catalyst is a new generation of environmentally friendly chemical with a high catalytic activity as the advantages property [5]. The ionic liquid is a kind of organic salt composed of anions and cations in a liquid state at a temperature below $100{ }^{\circ} \mathrm{C}$ [6]. The ionic liquid characteristics have many advantages such as negligible vapor pressure and have good solubility for organic and inorganic materials [7]. 
Microwave radiation can be used as a promising heating system in the biodiesel production [8, 9]. Microwave heating can enhance chemical reactions because it can transfer energy directly to the reactants such that the heat transfer is more effective than conventional heating and the reaction can take place more quickly [10]. Polar molecules interact to absorb microwave, and non-polar molecules will be inert. It can be analyzed that the polar solvents can lead to increase boiling point when heated by using microwave heating than conventional heating [11].

El Sherbiny et al. [9] showed that the synthesis of biodiesel from jatropha oil produce the highest yield of $94.7 \%$ with a reaction time of 2 minutes using microwave heating while conventional heating requires a reaction time of 1 hour. As our best knowledge, the optimization study of the biodiesel production using the mixture of the 1 butyl-3 methyl imidazolium hydrogen sulphate ionic liquid with $\mathrm{NaOH}$ as a catalyst still not available in the published literature. Therefore, in the present study, the effect of the use of ionic liquid $+\mathrm{NaOH}$ catalyst and microwave radiation on transesterification of Nyamplung oil were investigated and optimized using Response Surface Methodology (RSM). This optimization method was used, since it is very suitable for the exploration of complex processes [12]. RSM with a central composite design was used to optimize the transesterification of Nyamplung oil with respect to the catalyst concentration, the temperature and the molar ratio methanol to oil.

\section{Materials and Methods}

\subsection{Materials}

The ionic liquid of 1 butyl-3 methyl imidazolium hydrogensulfate $\left(\mathrm{BMIMHSO}_{4}\right.$ ) with the purity of $95.0 \%$ purchased from Sigma- Aldrich through PT. Hepilab Sukses Bersama supplier, Indonesia. Methanol and sodium hydroxide have the purity of $99.9 \%$ and $99.0 \%$, respectively and supplied by Merck through PT. Hepilab Sukses Bersama supplier, Indonesia. Phosphoric acid with the purity of $85.0 \%$ was supplied by Sigma-Aldrich and technical grade sodium carbonate was obtained from PT. Hepilab Suskes Bersama supplier. Nyamplung crude oil contains $12.9 \%$ of FFA and viscosity of $63.03 \mathrm{~mm}^{2} / \mathrm{s}$ was obtained from Kroya, Cilacap, Indonesia.

\subsection{Methods}

\subsubsection{Pretreatment}

Crude Nyamplung oil contains gums and free fatty acid (FFA) of $12.9 \%$, it was purified using degumming and neutralization method to remove the impurities present in the oil. Phosphoric acid with the concentration of $20 \%$ was prepared, it was then added into the oil with amount of $0.3 \%(\mathrm{v} / \mathrm{wt})$. The mixture was then heated on a hot plate at $70{ }^{\circ} \mathrm{C}$ for 25 minutes. Furthermore, saturated solution of sodium carbonate with a concentration of $20 \mathrm{ml} / 100 \mathrm{ml}$ oil was added into the oil. It was then heated at $70{ }^{\circ} \mathrm{C}$ for 1 hour. Soap and other impurities were separated from the oil by decantation for 24 hours. The oil from decantation result was washed with water at $60-70{ }^{\circ} \mathrm{C}$ to obtain the neutral $\mathrm{pH}$ of the Oil. Pure Nyamplung oil has free fatty acid of $0.21 \%$.

\subsubsection{Transesterification assisted by Microwave power}

Transesterification reaction was conducted in a fournecked batch reactor with a volume of $500 \mathrm{~mL}$ equipped with microwave, condenser, temperature sensor and magnetic stirrer set at $600 \mathrm{rpm}$. A fixed amount of Nyamplung oil was placed into the reactor, which was preheated to the desired temperatures in a microwave before starting the reaction. The amount of $\left[\mathrm{BMIMHSO}_{4}\right]$ and $\mathrm{NaOH}$ catalyst at a ratio of 1:1 was varied at a range of 0.5-1.5\% to the oil. The molar ratio of methanol to oil was varied from 6 to $12 \mathrm{~mole} / \mathrm{mole}$ and the reaction temperature from 60 to $80{ }^{\circ} \mathrm{C}$. The reaction time of microwave heating was fixed at 6 minutes. The reaction mixture was added into the flask separator until two phases are formed in equilibrium. The upper phase consisted of methyl esters, and the lower phase contained the glycerol.

The methyl ester phase was injected into Gas Chromatography-Mass Spectrometry (GC-MS) (QP2010S SHIMADZU) with a syringe to determine the concentration of methyl ester (oleic acid, linoleic acid, stearic acid and palmitic acid). The column used was restek (RTX-1, $100 \%$ dimethylpolysiloxane) $30 \mathrm{~m} \times 0.25 \mathrm{~mm} \times 0.25 \mu \mathrm{m}$ ). Within the GC-MS, the samples were analyzed with an oven temperature of $65^{\circ} \mathrm{C}$ (8 minutes) and raised $10{ }^{\circ} \mathrm{C} \mathrm{min}{ }^{-1}$ up to a temperature of $250{ }^{\circ} \mathrm{C}$ and held for 20 minutes. The methyl ester yield is calculated using Eq. (1) [3]

$$
\text { Methyl ester yield }=C \times W_{b} / W_{\text {oil }} \times 100 \% \text {. }
$$

Where is methyl ester content (\%), represents weight of biodiesel production (g) and $W_{\text {oil }}$ is the weight of initial amount of Nyamplung oil (g).

\subsection{Response surface methodology design}

RSM with a Central Composite Design (CCD) was employed to design the experiment and investigate the influence of the three independent variables. The independent variables 
were catalyst concentration, reaction temperature and methanol to oil molar ratio. Catalyst concentration at 0.5 , 1 and $1.5 \%$ wt, temperature reaction at 60,70 and $80{ }^{\circ} \mathrm{C}$ and molar ratio methanol to oil of 6,9 and $12 \mathrm{~mole} / \mathrm{mole}$. The methyl ester yield was selected as the responses for the combination of these independent variables. The real value of the independent variables was transformed to the coded variables, shown in Table 1.

The yield of methyl ester is expressed as a function of a set of independent variables, following a second order polynomial equation as shown in Eq. (2) [13]

$$
y=\beta_{0}+\sum_{i=1}^{k} \beta_{i} x_{i}+\sum_{\substack{i=1 \\ i<j}}^{k-1} \sum_{j=2}^{k} \beta_{i j} x_{i} x_{j}+\sum_{i=1}^{k} \beta_{i i} x_{i}^{2}+\varepsilon .
$$

Where various $x_{i}$ and $x_{j}$ are independent variables, respectively, $y$ is response variables; $\beta_{0}, \beta_{i}, \beta_{i i}, \beta_{i j}$ are the regression coefficients and $k$ is the number of variables.

In this investigation, the three independent variables were catalyst concentration $\left(X_{1}\right)$, temperature reaction $\left(X_{2}\right)$ and molar ratio methanol to oil $\left(X_{3}\right)$ and $Y$ was response variable (methyl ester yield) yielding the Eq. (3)

$$
\begin{aligned}
& Y=\beta_{0}+\beta_{1} X_{1}+\beta_{2} X_{2}+\beta_{3} X_{3}+\beta_{12} X_{1} X_{2}+\beta_{13} X_{1} X_{3} \\
& +\beta_{23} X_{2} X_{3}+\beta_{11} X_{1}^{2}+\beta_{22} X_{2}^{2}+\beta_{33} X_{3}^{2} .
\end{aligned}
$$

\subsection{Statistical Analysis}

The Statistica 6.0 software was used to analyze experimental data and calculate the value of the prediction response. The software can also generate graphs plot response values which are predicted in 3-D plot. The significance evaluation between the mean of methyl ester concentrations with different experimental runs were statistically defined at $(p)<0.05$. The validity of developed model equation was verified by conducting an experimental study.

\section{Results and Discussion}

\subsection{The development model for the methyl ester yield prediction}

Model parameters in Eq. (3) were statistically determined by using response surface methodology (RSM) based on Central Composite Design (CCD). Table 2 shows the

Table 1 Experimental range and factor level of process variable

\begin{tabular}{lccccc}
\hline \multirow{2}{*}{ Independent Variable } & \multicolumn{5}{c}{ Pattern Code } \\
& $-\alpha$ & -1 & 0 & +1 & $+\alpha$ \\
\hline Catalyst, \%wt & 0.2 & 0.5 & 1.0 & 1.5 & 1.8 \\
Temp, ${ }^{\circ} \mathrm{C}$ & 53.2 & 60.0 & 70.0 & 80.0 & 86.8 \\
$\mathrm{MeOH}: \mathrm{TG},(\mathrm{mole} / \mathrm{mole})$ & 4.0 & 6.0 & 9.0 & 12.0 & 14.1 \\
\hline
\end{tabular}

experimental design with three factors which are methanol to oil molar ratio, reaction temperature and catalyst concentration. The prediction model was validated with the experimental data to suggest that the appropriate predictive models to estimate the experimental data. Therefore, the model and the experimental data should have a high coefficient of correlation $\left(R^{2}\right)$. The analysis of variance (ANOVA) of experimental data is shown in Table 3. It shows that the $R^{2}$ value of the model is 0.97014 indicating that $97.014 \%$ of the experimental data can fit to the predicted value of the methyl ester yield model (Fig. 1).

In addition, the $p$-value of the model parameters indicates that the developed model predictions parameters were significant [14]. The $p$-value mostly below 0.05 , except for $\beta_{12}$ in yield model $(p=0.06029), \beta_{13}$ in the yield model $(p=0.615856)$ and $\beta_{23}$ in the yield model ( $\left.p=0.805990\right)$. The results of the analysis stated a mathematical model for the methyl esters yield prediction with a very well fit to the second order polynomial formula as defined in Eq. (4) by neglecting insignificant variables which are $\beta_{12}, \beta_{13}$ and $\beta_{23}$

$$
\begin{aligned}
& Y_{\text {methyl ester }}=-63.8588+19.4043 X_{1}+3.4187 X_{2} \\
& +4.9059 X_{3}-14.8547 X_{1}^{2}-0.0257 X_{2}^{2}-0.2461 X_{3}^{2} .
\end{aligned}
$$

\begin{tabular}{|c|c|c|c|c|c|}
\hline Run & $\begin{array}{c}\text { Catalyst } \\
(\% \mathrm{wt})\end{array}$ & $\begin{array}{c}\text { Temp } \\
\left({ }^{\circ} \mathrm{C}\right)\end{array}$ & $\begin{array}{c}\text { MeOH:TG, } \\
\text { mole/mole }\end{array}$ & $\begin{array}{c}\text { Experimental } \\
\text { Value } \\
\text { Yield (\%) }\end{array}$ & $\begin{array}{l}\text { Predicted } \\
\text { Value } \\
\text { Yield (\%) }\end{array}$ \\
\hline 1 & 0.5 & 60.0 & 06.0 & 81.37 & 82.50 \\
\hline 2 & 0.5 & 60.0 & 12.0 & 87.49 & 87.10 \\
\hline 3 & 0.5 & 80.0 & 06.0 & 82.40 & 81.12 \\
\hline 4 & 0.5 & 80.0 & 12.0 & 85.83 & 86.16 \\
\hline 5 & 1.5 & 60.0 & 06.0 & 83.91 & 84.13 \\
\hline 6 & 1.5 & 60.0 & 12.0 & 87.81 & 89.63 \\
\hline 7 & 1.5 & 80.0 & 06.0 & 85.51 & 86.44 \\
\hline 8 & 1.5 & 80.0 & 12.0 & 91.95 & 92.37 \\
\hline 9 & 0.2 & 70.0 & 09.0 & 79.91 & 80.88 \\
\hline 10 & 1.8 & 70.0 & 09.0 & 89.22 & 87.47 \\
\hline 11 & 1.0 & 53.2 & 09.0 & 87.63 & 86.83 \\
\hline 12 & 1.0 & 86.8 & 09.0 & 87.96 & 87.98 \\
\hline 13 & 1.0 & 70.0 & 04.0 & 83.73 & 83.99 \\
\hline 14 & 1.0 & 70.0 & 14.1 & 93.88 & 92.85 \\
\hline $15 \mathrm{C}$ & 1.0 & 70.0 & 09.0 & 94.04 & 94.68 \\
\hline $16 \mathrm{C}$ & 1.0 & 70.0 & 09.0 & 95.18 & 94.68 \\
\hline $17 \mathrm{C}$ & 1.0 & 70.0 & 09.0 & 94.63 & 94.68 \\
\hline $18 \mathrm{C}$ & 1.0 & 70.0 & 09.0 & 95.23 & 94.68 \\
\hline $19 \mathrm{C}$ & 1.0 & 70.0 & 09.0 & 94.20 & 94.68 \\
\hline
\end{tabular}

Table 2 The set of experimental variables based on Central Composite Design and observed response of methyl ester yield in the synthesis of biodiesel with catalyst IL $+\mathrm{NaOH}$ and assisted microwave. 


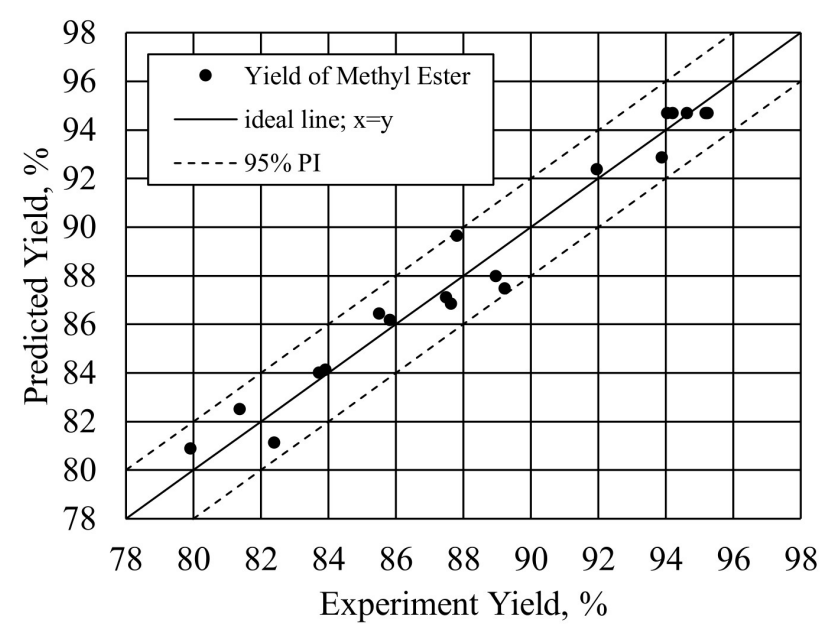

Fig. 1 The correlation between the predicted value and experimental value of biodiesel yield $\left(R^{2}=0.9701\right)$ with $95 \%$ of Prediction Interval (PI).

\subsection{Effect of transesterification parameters to methyl ester yield}

The effect of parameters to the methyl ester yield is the catalyst concentration, the temperature, and the molar ratio methanol to oil were studied. This parameter affects the reaction rate and yield of methyl ester. Temperature, the ratio of molar alcohol to oil and catalyst concentration are the most important parameters for biodiesel production [15]. High temperatures will increase the solubility of oil in methanol, thus increasing the reaction rate and yield of methyl ester [16].

The molar ratio of alcohol to oil is one of the most important variables affecting the yield of methyl ester. The stoichiometric ratio for transesterification requires three moles of alcohol and one mole of triglycerides to produce three moles of fatty acid alkyl esters and one mole of glycerol [17]. However, a high molar ratio of alcohol to vegetable oil interferes with the separation of glycerine because there is an increase in solubility. When glycerin stays in the solution, it causes the equilibrium to return to the left, decreasing the yield of methyl ester [18]. The catalyst concentration can affect the yield of methyl ester. Increased catalyst concentration will increase the conversion of triglycerides and increase the yield of methyl esters. the optimal value of catalyst concentration $(\mathrm{NaOH})$ is $1.5 \% \mathrm{wt}$ and the addition of an excess alkali catalyst causes more triglycerides to react with alkaline catalysts and form more soap [17].

The results of the analysis in Fig. 2 shows that the catalyst concentration effect to the yield of methyl ester, with increasing concentration catalyst to higher yield. In Table 3, the parameter catalyst concentration has a value of $p=0.022637$,
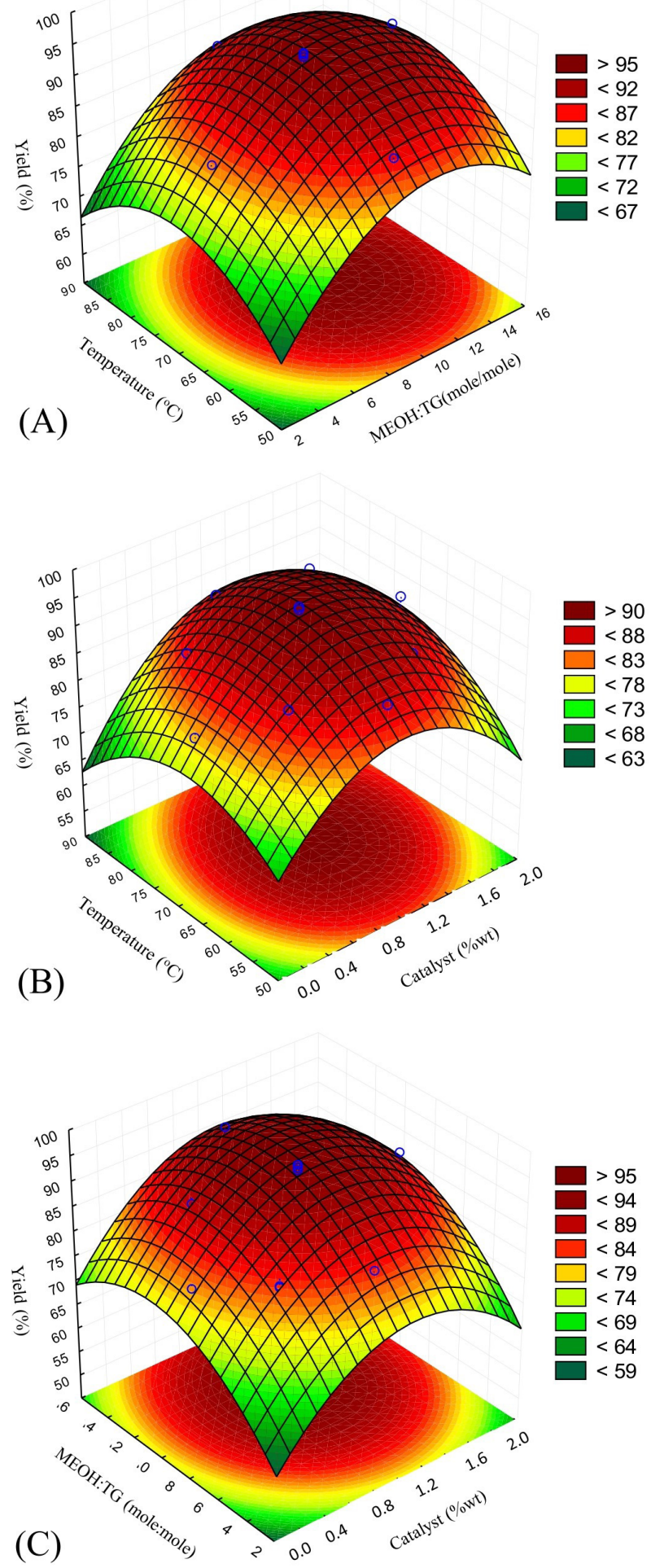

Fig. 2 The 3D response surfaces profile of methyl ester yield as affected by independent variable

catalyst concentration significantly affect to the methyl ester yield. At a constant temperature conditions of $70.5^{\circ} \mathrm{C}$ and a molar ratio methanol to oil of $9.0 \mathrm{~mole} / \mathrm{mole}$, the methyl ester 
Table 3 Prediction regression coefficients for second order polynomial models of methyl ester yield

\begin{tabular}{lcccc}
\hline Parameter & $\begin{array}{c}\text { Predicted } \\
\text { Coefficients }\end{array}$ & $\begin{array}{c}\text { Standard } \\
\text { Error }\end{array}$ & DF & $p$ value \\
\hline$\beta_{0}$ & -63.8588 & 20.2103 & 1 & 0.0116 \\
$\beta_{1}$ & 19.4043 & 7.0672 & 1 & 0.0226 \\
$\beta_{2}$ & 3.4187 & 0.4858 & 1 & 0.0001 \\
$\beta_{3}$ & 4.9059 & 1.2348 & 1 & 0.0032 \\
$\beta_{12}$ & 0.1841 & 0.0857 & 1 & $0.0603(p>0.05)$ \\
$\beta_{13}$ & 0.1485 & 0.2857 & 1 & $0.6158(p>0.05)$ \\
$\beta_{23}$ & 0.0036 & 0.0143 & 1 & $0.8059(p>0.05)$ \\
$\beta_{11}$ & -14.8547 & 1.3126 & 1 & 0.0000 \\
$\beta_{22}$ & -0.0257 & 0.0033 & 1 & 0.0000 \\
$\beta_{33}$ & -0.2461 & 0.0365 & 1 & 0.0001 \\
Lack of fit & & & 5 & \\
$R^{2}$ & 0.9701 & & Adj & 0.9402 \\
$\beta_{0}$ & -63.8588 & & $R^{2}$ & 0.0116 \\
\hline
\end{tabular}

yield increased from $84.5 \%$ to $88.5 \%$ across a concentration catalyst ranging between 0.16 and $1.0 \% \mathrm{wt}$.

Table 3 also shows the $p$-value of 0.000061 for the temperature, significantly affect the methyl ester yield. Under a constant conditions of a concentration catalyst of $1.0 \%$ wt and a molar ratio methanol to oil of $9.0 \mathrm{~mole} / \mathrm{mole}$, the methyl ester yield increased from $88.0 \%$ to $89.0 \%$, across a temperature ranging between 50.0 and $70.5{ }^{\circ} \mathrm{C}$.

In addition, for the molar ratio of methanol to oil with a value of $p=0.003239$, significantly affect the yield of methyl ester. Under fixed conditions of the concentration catalyst of $1.0 \%$ wt and temperature of $70.5{ }^{\circ} \mathrm{C}$, the methyl ester yield increased from $82.5 \%$ to $88.5 \%$ across a molar ratio methanol to oil ranging between 2.0 and 9.0 mole/mole.

\subsection{Optimization of operating conditions of transesterification reaction assisted by microwave power}

A linear regression model to determine the optimum value of the concentration catalyst, reaction temperature and the methanol to oil molar ratio using RSM optimization is shown in Eq. (3). The results of this optimization analysis, the optimum value will be the catalyst concentration $\left(X_{1, \text { op }}\right)$, temperature $\left(X_{2, \text { opt }}\right)$, and the molar ratio methanol to oil $\left(X_{3, o p t}\right)$. By using the optimal parameters, optimum yield is recalculated using Eq. (3).

Optimization results in Table 4 shows that the optimum conditions of microwave-assisted transesterification reaction of $X_{1, \text { opt }}=0.298, X_{2, \text { opt }}=0.1328$ and $X_{3, \text { opt }}=0.61267 \mathrm{rep}$ resents the real condition of the catalyst concentration of
Table 4 The optimum value of yield methyl ester.

\begin{tabular}{lcccc}
\hline & \multicolumn{2}{c}{ Optimum condition } & \multicolumn{2}{c}{ Value of response $\left(Y_{\text {opt }}\right)$} \\
Variables & Coded & $\begin{array}{c}\left(X_{\text {opt }}\right) \\
\text { Real value }\end{array}$ & Predicted & Experiment \\
\hline Catalyst, \%wt & 0.29 & 1.2 & & \\
$\begin{array}{l}\text { Temperature, } \\
{ }^{\circ} \mathrm{C}\end{array}$ & 0.13 & 71.3 & $95.8 \%$ & $94.6 \%$ \\
$\begin{array}{l}\text { MeOH:TG, } \\
\text { (mole/mole) }\end{array}$ & 0.61 & 10.8 & & \\
\% error & & & & $1.26 \%$ \\
\hline
\end{tabular}

$1.2 \% \mathrm{wt}, 71.3^{\circ} \mathrm{C}$ temperature and molar ratio of methanol to oil 10.8 mole/mole (Table 4 ). The results showed that the optimum yield was obtained in the range of studied variables as shown in Table 2. Optimum operation condition to produce methyl ester of $95.80 \%$ was successfully predicted by the model. The result of the experiment (Table 4) showed that a methyl ester yield was $94.6 \%$ which are compared to the predicted value.

Microwave-assisted biodiesel production is shorter than conventional heating system. Handayani et al. [19] produced biodiesel from Nyamplung oil with catalyst $\left[\mathrm{BMIMHSO}_{4}\right]$ (1) $+\mathrm{NaOH}$ (1) amount of $1 \%$ wt using conventional heating obtained yield $(93.99 \%)$ for $180 \mathrm{~min}-$ utes, while using microwave assisted esterification method obtained the yield $92.81 \%$ for 6 minutes. Lin et al. [3] indicated that the transesterification reaction with conventional heating systems using catalyst concentrations of $\mathrm{NaNH}_{2} 1 \% \mathrm{wt}$, reaction temperature of $65^{\circ} \mathrm{C}$, molar methanol-to-oil ratio of 8 , and reaction time of 105 minutes, the yield was $95.6 \%$ while with microwave for reaction time of 7 minutes obtained yield of $96.2 \%$.Methanol is a high polarity organic solvent and has a high absorption capacity of microwaves energy. Both of these properties are factors that support the rapid transesterification reaction caused by dipolar polarization and ionic conduction [20]. Polar solvents can make an increase in boiling point when heated using a microwave rather than conventional heating [11].

Microwave heating has several advantages over conventional heating such as reducing excess heat from the material surface, reducing thermal gradients, selective materials and volumetric heating, fast start-up and stop and reverse thermal effects [20]. While, conventional methods provide heterogeneous heating effects, depending on thermal conductivity, specific heat, and density of vessel materials. Vessel surface temperature is higher than the sample temperature in vessel. There are conventional energy sources are lost to the environment through material conduction and convection currents. Whereas the 
microwave will transfer microwave energy directly to the reactant, so that the interaction of energy from the microwave with the reactant produces effective heating [10].

\subsection{Analysis of methyl esters derived from Nyamplung oil}

The biodiesel from Nyamplung oil was analyzed by GCMS, The GC Chromatograms and fatty acid compositions of biodiesel are presented in Fig. 3 and Table 5 respectively. The methyl esters composition, chain length and saturation level of oil are important characteristics that indicate the physical state of oil and biodiesel. This characteristic influences cetane numbers and cold flow properties such as cloud point, pour point, cold filter plugging point and cold soak filtration test of biodiesel [21]. The chain length and saturation level affect the density and viscosity of biodiesel. Density increases by decreasing chain length and increasing number of double bonds. While the viscosity increases by increasing chain length and inversely related to the number of double bonds [22].

The GCMS analysis indicate that the biodiesel contained mainly methyl esters of oleic acid (C18:1), linoleic acid (C18:2), stearic acid (C18:0) and palmitic acid (C16:0),

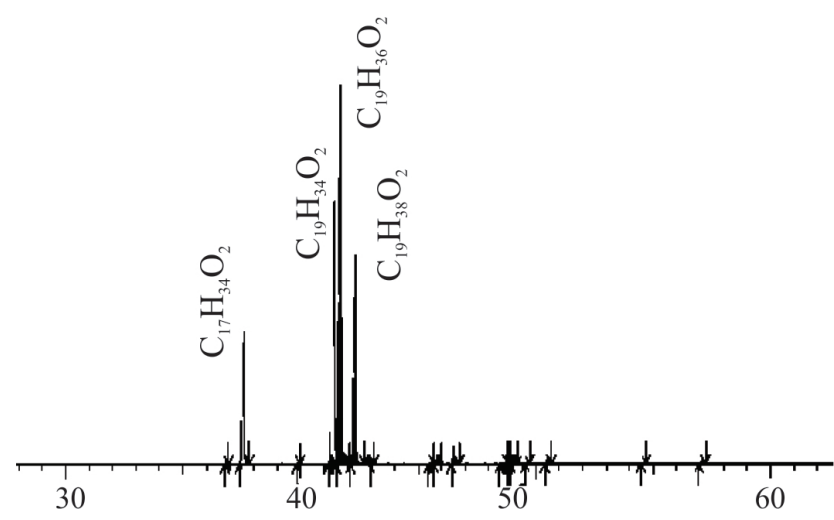

Fig. 3 GC chromatogram of fatty acid methyl ester (biodiesel)

Table 5 FAMEs composition of synthesized biodiesel

\begin{tabular}{lcccc}
\hline $\begin{array}{l}\text { Peak } \\
\text { no }\end{array}$ & $\begin{array}{c}\text { Retention } \\
\text { time } \\
(\text { min) }\end{array}$ & Identified compounds & $\begin{array}{c}\text { Molecule } \\
\text { formula }\end{array}$ & $\%$ \\
\hline 1 & 36.84 & Methyl oleic & $\mathrm{C}_{19} \mathrm{H}_{36} \mathrm{O}_{2}$ & 0.13 \\
2 & 37.58 & Methyl palmitate & $\mathrm{C}_{17} \mathrm{H}_{34} \mathrm{O}_{2}$ & 9.52 \\
3 & 39.89 & Methyl margarate & $\mathrm{C}_{18} \mathrm{H}_{36} \mathrm{O}_{2}$ & 0.06 \\
4 & 41.43 & Methyl linoleate & $\mathrm{C}_{19} \mathrm{H}_{34} \mathrm{O}_{2}$ & 25.49 \\
5 & 41.72 & Methyl oleic & $\mathrm{C}_{19} \mathrm{H}_{36} \mathrm{O}_{2}$ & 44.59 \\
6 & 42.32 & Methyl stearate & $\mathrm{C}_{19} \mathrm{H}_{38} \mathrm{O}_{2}$ & 17.70 \\
7 & 45.86 & Methyl heptadec-10-enoate & $\mathrm{C}_{18} \mathrm{H}_{34} \mathrm{O}_{2}$ & 0.20 \\
8 & 46.51 & Methyl arachidate & $\mathrm{C}_{21} \mathrm{H}_{42} \mathrm{O}_{2}$ & 1.14 \\
9 & 48.53 & Methyl heneicosanoate & $\mathrm{C}_{22} \mathrm{H}_{44} \mathrm{O}_{2}$ & 0.02 \\
10 & 50.48 & Methyl behenate & $\mathrm{C}_{23} \mathrm{H}_{46} \mathrm{O}_{2}$ & 0.34 \\
11 & 54.57 & Methyl tetracosanoate & $\mathrm{C}_{25} \mathrm{H}_{50} \mathrm{O}_{2}$ & 0.07 \\
\hline
\end{tabular}

with compositions of $44.72 \%, 25.49 \%, 17.70 \%$ and $9.52 \%$. Rashid et al. [12] stated that rice bran biodiesel contained fatty acid consisting mainly of oleic acid, linoleic, palmitate and stearate, respectively $43.1 \%, 32.2 \%, 18.8 \%$ and $1.4 \%$.

\subsection{Synthesized Biodiesel Physico-chemical properties}

The optimum product biodiesel fuel properties result are listed in Table 6. It is observed that this biodiesel obtained from Nyamplung oil in the presence of $\mathrm{BMIMHSO}_{4}+$ $\mathrm{NaOH}$ as a catalyst and microwave assisted, fuel properties meets the ASTM D-6751 standards.

Table 6 shows the density biodiesel Nyamplung $868 \mathrm{~g} / \mathrm{ml}$. This value is included in ASTM range density biodiesel values between 850 and $894 \mathrm{~g} / \mathrm{ml}$. Density is an important parameter in airless combustion system that affect the efficiency of atomization and the content of alkyl ester [23].

High viscosity values will lead to unfavorable atomization of fuel, incomplete combustion and carbon deposition in the injector [23]. The viscosity of Nyamplung biodiesel is $5.878 \mathrm{~mm}^{2} / \mathrm{s}$, it meets the national standard up to $6 \mathrm{~mm}^{2} / \mathrm{s}$. The acid value of biodiesel provides free fatty acid content in biodiesel and fuel aging rates during storage. The value of this parameter is limited to maximum of $0.8 \mathrm{mg} \mathrm{KOH} / \mathrm{g}$ and acid value of Nyamplung biodiesel of $0.23 \mathrm{mg} \mathrm{KOH} / \mathrm{g}$. The cetane number biodiesel Nyamplung of 70.9, where standard national determine the cetane number of fuel at least 48 . The higher cetane number the better ignition and refinement of fuel. Biodiesel has a higher cetane number than fossil fuel, resulting in higher combustion efficiency [23].

Flash point is a parameter that determines the safety of fuel in storage. The high flash point has a fire risk, where

Tabel 6 Synthesized biodiesel physicochemical properties

\begin{tabular}{|c|c|c|c|}
\hline Property & Unit & $\begin{array}{l}\text { Synthesized } \\
\text { biodiesel }\end{array}$ & $\begin{array}{l}\text { ASTM } \\
\text { D-6751 }\end{array}$ \\
\hline Specific Gravity at $60 / 60^{\circ} \mathrm{F}$ & - & 0.8782 & \\
\hline Density $15^{\circ} \mathrm{C}$ & $\mathrm{gr} / \mathrm{ml}$ & 868 & $860-894$ \\
\hline $\begin{array}{l}\text { Kinematic Viscosity at } \\
40{ }^{\circ} \mathrm{C}\end{array}$ & $\mathrm{mm}^{2} / \mathrm{s}$ & 5.878 & $1.9-6.0$ \\
\hline Flash Point & ${ }^{\circ} \mathrm{C}$ & 185 & $130 \mathrm{~min}$ \\
\hline Color ASTM & - & 1.5 & - \\
\hline Water Content & \%vol. & Nil & $0.030 \max$ \\
\hline Pour Point & ${ }^{\circ} \mathrm{C}$ & 9 & -15 to 10 \\
\hline Conradson Carbon Residue & $\%$ wt. & 0.0021 & $0.05 \max$ \\
\hline Gross Heating Value & BTU/lb & 19404 & \\
\hline Distillation $90 \%$ & ${ }^{\circ} \mathrm{C}$ & 323 & $360 \max$ \\
\hline Acid Value & $\mathrm{mgKOH} / \mathrm{g}$ & 0.23 & $0.8 \max$ \\
\hline Cetane number & - & 70.9 & $48 \mathrm{~min}$ \\
\hline
\end{tabular}


the national standard flash point value is specified at least $130^{\circ} \mathrm{C}$. Nyamplung biodiesel has a flash point of $185^{\circ} \mathrm{C}$.

Carbon residue is defined as the amount of carbonaceous matter left after evaporation and pyrolysis of fuel sample under specified condition. Nyamplung biodiesel has a carbon residue of $0.0021 \% \mathrm{wt}$, it meets the national standard. The Nyamplung biodiesel product meets ASTM D-6751 standard.

\section{Conclusion}

Optimization of the biodiesel production with an ionic liquid $+\mathrm{NaOH}$ catalyst-assisted microwave have been studied using Response Surface Methodology (RSM) based on Central Composite Design (CCD). Ionic liquid $+\mathrm{NaOH}$ catalyst and assisted microwave can improve biodiesel yield. The results showed that the concentration catalyst, the temperature reaction and the molar ratio methanol to oil have a significant effect on the methyl ester yield. The optimum conditions for the transesterification process of Nyamplung (Calophyllum inophyllum) oil for 6 minutes are the catalyst concentration of $1.2 \% \mathrm{wt}$, the

\section{References}

[1] Ong, H. C., Mahlia, T. M. I., Masjuki, H. H., Norhasyima, R. S. "Comparison of palm oil, Jatropha curcas and Calophyllum inophyllum for biodiesel: A review", Renewable and Sustainable Energy Reviews, 15(8), pp. 3501-3515, 2011. https://doi.org/10.1016/j.rser.2011.05.005

[2] Lin, C.-C., Hsiao, M.-C. "Effect of Catalyst Amount, Reaction Temperature and Methanol / Oil Molar Ratio on Conversion Rate of Soybean Oil Assisted by Ultrasonic Mixing and Closed Microwave Irradiation", International Journal of Engineering Inventions, 1(6), pp. 40-48, 2012. [online] Available at: www.ijeijournal.com/papers/ v1i6/F0164048.pdf [Accessed: 27 March 2018]

[3] Lin, Y.-C., Yang, P.-M., Chen, S.-C., Tu, Y.-T., Lin, J.-F. "Biodiesel production assisted by 4-allyl-4-methylmorpholin-4-ium bromine ionic liquid and a microwave heating system", Applied Thermal Engineering, 61(2), pp. 570-576, 2013. https://doi.org/10.1016/j.applthermaleng.2013.08.038

[4] Fan, M., Huang, J., Yang, J., Zhang, P. "Biodiesel production by transesterification catalyzed by an efficient choline ionic liquid catalyst", Applied Energy, 108, pp. 333-339, 2013. https://doi.org/10.1016/j.apenergy.2013.03.063

[5] Andreani, L., Rocha, J. D. "Use of ionic liquid in biodiesel production: A review", Brazilian Journal of Chemical Engineering, 29(1), pp. 1-13, 2012.

https://doi.org/10.1590/S0104-66322012000100001

[6] Mohammad Fauzi, A. H., Amin, N. A. S. "An overview of ionic liquids as solvents in biodiesel synthesis", Renewable and Sustainable Energy Reviews, 16(8), pp. 5770-5786, 2012. https://doi.org/10.1016/j.rser.2012.06.022 temperature of $71.3{ }^{\circ} \mathrm{C}$ and the molar ratio of methanol to oil $10.8 \mathrm{~mole} / \mathrm{mole}$ to yield $95.8 \%$. The second order polynomial models were obtained to predict percentage conversion. Validation experiments were also carried out to verify the availability and the accuracy of the model, and the result showed that the predicted value was in agreement with the experimental value. The GCMS analysis indicated that the biodiesel contained mainly of oleic acid (C18:1), linoleic acid (C18:2), stearic acid (C18:0) and palmitic acid (C16:0), with compositions of $44.72 \%$, $25.49 \%, 17.70 \%$ and $9.52 \%$. The physicochemical properties of Nyamplung Biodiesel have been tested based on the Indonesian National Standard, and the results were in accordance with ASTM D-6751 standard.

\section{Acknowledgement}

We gratefully thank Ministry of Research, Technology and Higher Education of Indonesia (Kemenristekdikti) for financial support for the Doctoral Dissertation Project in accordance with the research contract number 1744 / UN37.3.1 / LT / 2017.

[7] Welton, T. "Room-Temperature Ionic Liquids. Solvents for Synthesis and Catalysis", Chemical Reviews, 99(8), pp. 2071-2084, 1999. https://doi.org/10.1021/cr980032t

[8] Chen, K.-S., Lin, Y.-C., Hsu, K.-H., Wang, H.-K. "Improving biodiesel yields from waste cooking oil by using sodium methoxide and a microwave heating system", Energy, 38(1), pp. 151-156, 2012. https://doi.org/10.1016/j.energy.2011.12.020

[9] El Sherbiny, S. A., Refaat, A. A., El Sheltaway, S. T. "Production of biodiesel using the microwave technique", Journal of Advanced Research, 1(4), pp. 309-314, 2010. https://doi.org/10.1016/j.jare.2010.07.003

[10] Motasemi, F., Ani, F. N. "A review on microwave-assisted production of biodiesel", Renewable and Sustainable Energy Reviews, 16(7), pp. 4719-4733, 2012. https://doi.org/10.1016/j.rser.2012.03.069

[11] Perreux, L., Loupy, A. "A tentative rationalization of microwave effects in organic synthesis according to the reaction medium, and mechanistic considerations", Tetrahedron, 57(45), pp. 9199-9223, 2001. https://doi.org/10.1016/S0040-4020(01)00905-X

[12] Rashid, U., Anwar, F., Ansari, T. M., Arif, M., Ahmad, M. "Optimization of alkaline transesterification of rice bran oil for biodiesel production using response surface methodology", Journal of Chemical Technology and Biotechnology, 84(9), pp. 1364-1370, 2009. https://doi.org/10.1002/jctb.2191 
[13] Patil, P. D., Gude, V. G., Camacho, L. M., Deng, S. "MicrowaveAssisted Catalytic Transesterification of Camelina Sativa Oil", Energy and fuels, 24(2), pp. 1298-1304, 2010.

https://doi.org/10.1021/ef9010065

[14] Hadiyanto, H., Suttrisnorhadi, S. "Response surface optimization of ultrasound assisted extraction (UAE) of phycocyanin from microalgae Spirulina platensis", Emirates Journal of Food and Agriculture, 28(4), pp. 227-234, 2016. https://doi.org/10.9755/ejfa.2015-05-193

[15] Sajjadi, B., Aziz, A. R. A., Ibrahim, S. "Investigation, modelling and reviewing the effective parameters in microwave-assisted transesterification", Renewable and Sustainable Energy Reviews, 37, pp. 762-777, 2014.

https://doi.org/10.1016/j.rser.2014.05.021

[16] Handayani, P. A., Abdullah, Hadiyanto "Process Evaluation of Biodiesel Production from Nyamplung (Calophyllum inophyllum) Oil Enhanced by Ionic Liquid $+\mathrm{NaOH}$ Catalyst and Microwave Heating System", Journal of Physical Science, 29(Supp. 2), pp. 265-275, 2018. https://doi.org/10.21315/jps2018.29.s2.21

[17] Leung, D. Y. C., Wu, X., Leung, M. K. H. "A review on biodiesel production using catalyzed transesterification", Applied Energy, 87(4), pp. 1083-1095, 2010.

https://doi.org/10.1016/j.apenergy.2009.10.006
[18] Meher, L. C., Sagar, D. V., Naik, S. N. "Technical aspects of biodiesel production by transesterification - a review", Renewable and Sustainable Energy Reviews, 10(3), pp. 248-268, 2006. https://doi.org/10.1016/j.rser.2004.09.002

[19] Handayani, P. A., Abdullah, A., Hadiyanto, H. "Biodiesel Production from Nyamplung (Calophyllum inophyllum) Oil using Ionic Liquid as A Catalyst and Microwave Heating System", Bulletin of Chemical Reaction Engineering \& Catalysis, 12(2), pp. 293-298, 2017 https://doi.org/10.9767/bcrec.12.2.807.293-298

[20] Gude, V. G., Patil, P., Martinez-Guerra, E., Deng, S., Nirmalakhandan, N. "Microwave energy potential for biodiesel production", Sustainable Chemical Processes, 1(5), pp 1-31, 2013. https://doi.org/10.1186/2043-7129-1-5

[21] Meher, L. C., Churamani, C. P., Arif, M., Ahmed, Z., Naik, S. N. "Jatropha curcas as a renewable source for bio-fuels - A review", Renewable and Sustainable Energy Reviews, 26, pp. 397-407, 2013. https://doi.org/10.1016/j.rser.2013.05.065

[22] Mittelbach, M., Remschmidt, C. "Biodiesel: the comprehensive handbook", 1st ed., Martin Mittelbach, Graz, Austria, 2004.

[23] Enweremadu, C. C., Mbarawa, M. M. "Technical aspects of production and analysis of biodiesel from used cooking oil A review", Renewable and Sustainable Energy Reviews, 13(9), pp. 2205-2224, 2009.

https://doi.org/10.1016/j.rser.2009.06.007 